Jadwiga Kozłowska-Doda

ORCID: https://orcid.org/0000-0001-7567-178X

Uniwersytet Marii Curie-Skłodowskiej, Lublin

\title{
Przesiedleńcy ze strefy wykluczenia po katastrofie atomowej w Czarnobylu: problemy z zadomawianiem się w nowej przestrzeni
}

\author{
Evacuees from the Exclusion Zone after the Chernobyl nuclear \\ disaster: problems with settling in a new space
}

\begin{abstract}
After the Chernobyl nuclear disaster, the so-called Chernobyl Exclusion Zone, covering the area within the $30 \mathrm{~km}$ radius from the nuclear reactor site, was established (also in Belarus). All people were evacuated from the zone and displaced to "clean" territory. For the purpose of the current paper, reports of witnesses from the documental prose, dialectal texts, publications and Belarus Archives of Oral History were analysed in an attempt to find in their narratives the answers to the following questions: who the people called "chernobyltsy" (literally: the Chernobyl ones) are and in what way they were and are seen by other people, especially just after the disaster; what the reaction of the people to the process of evacuation was; what the indigenous people during the evacuation took with them; what they left at their homes and why; what their attitude towards new comfortable houses and flats was; in what way they tried to adapt themselves to new environment; where they buried the dead; and whether they successfully settled in their new places of residence. Having analysed the reports and arranged them according to the phenomenology of the area based on the report of H. Buczyńska-Garewicz, the category of "rootedness" of S. Weil and J. Tischner, A. van Gennep's theory of rites of passage", the author concludes that a great number of "chernobyltsy" are deeply rooted in their motherland; an approach that excludes the possibility of expanding the definition of "home" and "the sense of settlement". Those people usually suffer at their new places of residence and sometimes return home. The only strategies favouring their acceptance of a new place that have been observed are focusing on work, especially on working the land (an allotment), or focusing on the health of their children.

Keywords: the sense of settlement, rootedness, Chernobyl nuclear disaster, Belarus, oral history
\end{abstract}


Po katastrofie atomowej w Czarnobylu powstała (także na Białorusi) tzw. strefa wykluczenia - ok. $30 \mathrm{~km}$ od reaktora, z której mieszkańców przesiedlono na tereny „czyste”. Poddano analizie wypowiedzi świadków zawarte w prozie dokumentalnej, tekstach gwarowych, publicystyce oraz w Białoruskim Archiwum Historii Mówionej. W relacjach szukano odpowiedzi na pytania: kto to są czarnobylcy i jak ich postrzegają inni, zwłaszcza tuż po awarii, jaka była reakcja ludzi na ewakuację, co autochtoni wyjeżdżając zabierali ze sobą, co i dlaczego zostawiali na miejscu, jaki był ich stosunek do nowych komfortowych domów i mieszkań, jak się urządzali na nowym miejscu, gdzie chowali zmarłych oraz czy udało im się zadomowić w nowym locum. W wyniku analizy wypowiedzi oraz zestawieniu ich z rozważaniami nad fenomenologią przestrzeni, w oparciu o studium H. Buczyńskiej-Garewicz, pojęcia zakorzenienia S. Weil i J. Tischnera, koncepcję „rytów przejścia” A. van Gennepa, autorka dochodzi do wniosku, że większość czarnobylców jest głęboko zakorzeniona w ojcowiźnie, co nie daje możliwości rozszerzenia pojęcia „dom” i uniemożliwia „zadomowienie". Ludzie cierpią na nowym miejscu, czasem wracają do siebie. Jako strategie oswajania nowej przestrzeni zauważono jedynie skoncentrowanie się na pracy, najchętniej na roli (działce), lub na zdrowiu własnych dzieci.

Słowa kluczowe: zadomowienie, zakorzenienie, katastrofa atomowa w Czarnobylu, Białoruś, ustna historia

Odebrano / Received: 31.01.2019

Zaakceptowano / Accepted: 27.08.2019

\section{Wprowadzenie}

Badania nad konceptualizacją domu we współczesnym języku białoruskim doprowadziły do wniosków, że jest to miejsce - budynek, mieszkanie, w którym ktoś człowiek - mieszka. Żeby to miejsce było domem, potrzeba dużo czasu i sporo doświadczenia oraz myślenia, z którego „powstaje” dom. Trzeba oswoić miejsce i w nim się zadomowić, żeby móc przebywać wśród swoich. Jest to miejsce, z którym domownik jest związany emocjonalnie, tu wszystko jest jemu znane, tu jest autentyczny, pewny siebie, jest sobą. Jest to miejsce wydzielone z otoczenia (zamknięte, ograniczone), można w nim się odseparować i zamknąć. Jest to miejsce dostosowane do potrzeb człowieka: tu czuje się bezpieczny; tu może się schronić przed zimnem i opadami; może się wyspać i odpocząć; tu spożywa posiłki, myje się i załatwia potrzeby fizjologiczne; tu przebywa razem z innymi ludźmi (rodziną i przyjaciółmi); opiekuje się dziećmi; przekazuje wzory kulturowe (niekiedy); czasem jest także miejscem pracy; najczęściej jest miejscem wzajemnej akceptacji (miłości, życzliwości) domowników i gotowości wzajemnej pomocy; do domu człowiek chętnie powraca; w nim domownicy czekają na każdego członka rodziny ${ }^{1}$. Jerzy Bartmiński uznał dom białoruski za prototyp domu słowiańskiego: „W lingwokulturze białoruskiej przetrwały - jak się zdaje - najbardziej typowe (prototypowe) i archaiczne cechy domu słowiańskiego, domu wiejskiego, chłopskiego"2.

Do charakterystyki pojęcia DOM w języku białoruskim, idąc w ślady Jerzego Bartmińskiego i Iwony Bielińskiej-Gardziel, został wykorzystany model logiczno-

1 Kazlouskaja-Doda 2015, s. 168-169; Kozłowska-Doda 2015, s. 177-206.

2 Bartmiński 2018, s. 50. 
-pojęciowy, który jest sumą trzech domen: $\{[\text { PODMIOT }]+[\text { ZDARZENIE }]+[\text { LOCUM }]\}^{3}$, uzupełniono go o jeszcze jeden komponent, jak się wydaje bardzo ważny dla białoruskiej społeczności językowo-kulturowej, mianowicie, [SPOSÓB MYŚLENLA $]^{4}$. Powodem wprowadzenia tego składnika była analiza zachowań poszczególnych grup społecznych zamieszkujących $\mathrm{w} \mathrm{XX}$ wieku teren współczesnej Białorusi, a $\mathrm{z}$ różnych powodów wysiedlonych $z$ własnych mieszkań, m.in. zesłanych przez NKWD w okresie represji politycznych, ideologicznych, wyjeżdżających w ramach tzw. repatriacji do Polski, ale też przesiedlonych po awarii w Czarnobylu na tereny bardziej oddalone, mniej zanieczyszczone przez radionuklidy, tzw. „czyste”. Zarówno w odbiorze pierwszych, jak i drugich były to tragedie, z którymi nie mogli się pogodzić, a nowe miejsca zamieszkania odbierali jako miejsce przymusowego pobytu, tymczasowego przebywania, tęsknili za domem, który musieli zostawićs.

Jak pokazują badania nad „relacją zachodzącą pomiędzy człowiekiem a przestrzenią" ${ }^{\circ}$ zarówno publikacje na temat fenomenologii przestrzeni Hanny Buczyńskiej-Garewicz ${ }^{7}$,jak i koncepcje Edmunda Husserla czy Martina Heideggera ${ }^{8}$, które wpłynęły na poglądy polskiej badaczki, zamieszkiwania ${ }^{9}$ nie wolno rozpatrywać wyłącznie jako faktu przebywania w konkretnym miejscu. Zadomowienie w nowej przestrzeni jest złożonym i długotrwałym procesem ${ }^{10}$.

Odczucia przesiedleńców można porównać do doświadczeń pisarzy przebywających na obczyźnie (emigracji, wygnaniu). Świadectwa i utwory ostatnich były już nieraz przedmiotem rozważań i analiz badaczy literaturoznawców ${ }^{11}$. Francuska filozof Simone Weil wprowadziła pojęcie zakorzenienia ${ }^{12}$, którym posługiwali się też inni myśliciele, np. ks. Józef Tischner ${ }^{13}$.

${ }^{3}$ Bartmiński, Bielińska-Gardziel 2012, s. 22.

${ }^{4}$ Kazlouskaja-Doda 2015, s. 136.

${ }^{5}$ Por. Kazlouskaja-Doda 2015, s. 139.

${ }^{6}$ Dziuban 2007, s. 123.

${ }^{7}$ Buczyńska-Garewicz 2006.

${ }^{8}$ Heidegger 1977.

${ }_{9}$ Pojęcie wprowadzone przez Heideggera.

${ }^{10}$ Np. Kazlouskaja-Doda 2015, s. 137-166 . Podobnie por.: Legeżyńska 1996, s. 15.

${ }_{11}$ Np. Legeżyńska 1996, Dutka 2008, Budzik 2013.

${ }^{12}$ S. Weil wiąże zakorzenienie ze sferą wartości. „Zakorzenienie jest być może najważniejszą i równocześnie najbardziej zapoznaną potrzebą duszy ludzkiej, a przy tym jedną z najtrudniejszych do zdefiniowania. Istota ludzka zakorzenia się poprzez rzeczywisty, czynny i naturalny udział w istnieniu jakiejś wspólnoty, która zachowuje żywe skarby przeszłości i wybiega swoimi przeczuciami w przyszłość. Udział naturalny warunkują same przez się miejsce zamieszkania, urodzenie, zawód, otoczenie. Każda istota ludzka potrzebuje licznych korzeni. Całość niemal swego życia moralnego, intelektualnego, duchowego powinna ona otrzymać za pośrednictwem środowisk, do których z natury rzeczy należy” (Weil 1943/2004, s. 953).

${ }^{13} \mathrm{~J}$. Tischner utożsamia zakorzenienie z warsztatem pracy: „Pracować na tym świecie, znaczy zakorz enić się. Zakorzenienie człowieka w świecie jest również owocem wzajemności, która przybiera postać współpracy. Człowiek pracuje z kimś i dla kogoś [...]. Zakorzenienie to druga - obok zadomowienia - forma 


\section{Przedmiot badań}

Choć Czarnobyl leży na Ukrainie, skutki wybuchu reaktora elektrowni jądrowej oddalonej o $17 \mathrm{~km}$ od miasta dotknęły w dużej mierze mieszkańców sąsiedniego regionu Białorusi. Po katastrofie atomowej 1986 roku powstała (także na Białorusi) tzw. strefa wykluczenia ${ }^{14}$ - ok. $30 \mathrm{~km}$ od reaktora, z której mieszkańców przesiedlono na tereny „czyste”.

O katastrofie elektrowni atomowej w Czarnobylu i jej skutkach pisano wiele. $\mathrm{Na}$ temat wysiedlania ludności z terenów dotkniętych awarią opublikowano mnóstwo artykułów prasowych. Część publikacji z przełomu lat 80.-90., jak wypowiadają się świadkowie, ma niewiele wspólnego $\mathrm{z}$ prawdą, głównie $\mathrm{z}$ powodu cenzury panującej w ówczesnym Związku Radzieckim. Mimo próby ukrycia szczegółów tragedii przez ówczesny rząd ZSSR oraz bagatelizowania jej skutków, światło dzienne ujrzały liczne świadectwa wielu osób, autochtonów. Nieprawidłowości i uchybienia nie będą jednak przedmiotem niniejszych badań.

Wykorzystując materiały publicystyczne późniejszej prasy białoruskiej, głównie niezależnej, ale też regionalnej, prozę dokumentalną (autorstwa Swietłany Aleksijewicz, Borysa Saczanki, Siarhieja Bałachonaua), teksty gwarowe oraz relacje świadków umieszczone w elektronicznym Białoruskim Archiwum Historii Mówionej (Беларускі архіў вуснай гісторы $\left.i^{15}\right)$, podjęto próbę zarysowania strategii oswajania i zadomowiania przestrzeni, w której zostali osiedleni tzw. czarnobylcy ${ }^{16}$.

$\mathrm{Z}$ uwagi na trudności bezpośredniego dotarcia do ludzi doświadczonych przez Czarnobyl, materiały, stanowiące podstawę opracowania, są z tzw. „z drugiej ręki”, a mimo to ich częśc stanowią autentyczne relacje świadków, pochodzących z dialektologicznych badań terenowych oraz nagrań audio i wizualnych, zgromadzonych w Białoruskim Archiwum Historii Mówionej. Wykorzystano również wypowiedzi świadków przetworzone literacko, które najczęściej dublują odczucia przesiedlonych mieszkańców, zawarte w autentycznych świadectwach.

przywiązania do ziemi. Człowiek przywiązuje się do ziemi poprzez swą pracę. Głównym źródłem siły przywiązania są ci, dla których człowiek pracuje" (Tischner 2006, 183). Zakorzenienie w takim rozumieniu jest bliskie białoruskim „czarnobylcom”.

${ }^{14}$ Strefa wykluczenia oznacza wykluczenie terytorialne, jest to zamknięta strefa, tereny najbardziej dotknięte skutkami awarii jądrowej. Po katastrofie miejscowa ludność została ewakuowana. Jej część samowolnie powróciła do swoich domów. Siergiej Paskiewicz w sposób następujący opisuje reakcję starszych mieszkańców: „Starsi ludzie nigdy nie pogodzili się z ewakuacją, nie zdołali zaadaptować się w nowych miejscach, w których ich osiedlono. Spędzili całe życie pośród poleskich lasów, gdzie od wieków panowały szczególny styl życia, swoista mentalność. Specjalnie dla ewakuowanych - setki kilometrów od ich rodzinnych stron - zbudowano nowe wsie. Musieli przystosować się do nowych warunków życia, do nowej pracy, zbudować nowe relacje społeczne w obcym sobie środowisku. Nie wszyscy dali radę i część wróciła do porzuconych domów na skażonych promieniowaniem terenach” (Paskiewicz, 2016, s. 18-25).

${ }^{15}$ Biatoruskie Archiwum Historii Mówionej, dostęp: 30.01.2019. Por. też Iwanowa 2017.

${ }^{16}$ Ukraińscy badacze opisywali, w sposób szczątkowy, odczucia ludności po stronie ukraińskiej, por. m.in. Dmitrenko 2017, Łeszczenko 2017. 


\section{Odrębna kategoria społeczna, tzw. czarnobylcy}

Wydaje się w pełni uzasadnione przybliżenie polskiemu czytelnikowi osobnej grupy społecznej, do której przylgnęło określenie czarnobylcy. Przed wybuchem reaktora nikt o nich nie słyszał. Wydany dziesięć lat po awarii reaktora jednotomowy Stownik biatoruskiego jezyka literackiego notuje jedynie wyraz чарнобыль w znaczeniu 'wieloletnia roślina trawiasta, o czerwono-brązowych łodygach, drobnych czerwonawych lub żółtych kwiatach zebranych w wiechę, rodzaj piołunu ${ }^{17}$, 'bylica pospolita, Artemisia vulgaris ${ }^{18}$. Tuż po awarii $\mathrm{w}$ opinii publicznej stali się nimi wszyscy, którzy mieszkali w pobliżu elektrowni i częściowo zostali stamtąd wysiedleni oraz ci, którzy zajmowali się likwidacją awarii ${ }^{19}$. Znaczenie to zanotowane zostało przez leksykografów dopiero po ponad dwudziestu latach po katastrofie w Stowniku nowych wyrazów języka biatoruskiego: чарнобылеи 'ten, kto ucierpiał w wyniku awarii elektrowni atomowej w Czarnobylu'; 'likwidator awarii elektrowni atomowej w Czarnobylu', чарнобыльскі 'mający stosunek do awarii elektrowni atomowej w Czarnobylu, związany z nią ${ }^{20}$, czasem pojawiające się $\mathrm{w}$ tekstach $\mathrm{z}$ uszczegółowieniem jako czarnobylcy likwidatorzy [ліквідатыры-чарнобыльцы] oraz czarnobylcy przesiedleńcy [чарнобыльцы-перасялениы] . W niniejszym artykule zostało poddane analizie zachowanie ostatnich.

$\mathrm{Na}$ łamach kroniki dokumentalnej noblistki Swietłany Aleksijewicz o miejscowej ludności, pochodzenia głównie chłopskiego, wypowiadają się m.in. przewodnicząca Mohylewskiego Komitetu Kobiet „Dzieci Czarnobyla” Natalia Rosłowa oraz historyk Aleksandr Riewalski:

Była sobie patriarchalna wieś białoruska. Białoruska chata. Bez ubikacji i ciepłej wody, za to z ikoną, drewnianą studnią, rusznikami, serwetami. Z gościnnością. (...) Był las, było pole. Zachowała się wspólnota i resztki wolności: działka przydomowa, gospodarstwo, własna krowa. (...) Natalia Rosłowa, przewodnicząca Mohylewskiego Komitetu Kobiet „Dzieci Czarnobyla"21.

Wśród tych, którzy pracowali w czarnobylskiej elektrowni, było wielu ludzi ze wsi. W dzień pracowali przy reaktorze, a wieczorem na działce albo u rodziców w sąsiedniej wsi, gdzie kartofle do dziś jeszcze sadzi się łopatą, nawóz rozrzucali widłami... A wygrzebuje te kartofle - rękami... Ich świadomość miotała się miedzy epoką kamienną a epoką atomu. Tkwiła w obu epokach naraz. (...) Aleksandr Riewalski, historyk ${ }^{22}$.

\footnotetext{
${ }_{17}$ Por. Sudnik, Kryuko 1999, s. 744.

${ }^{18}$ Chylak-Schroeder, Głuszkowska-Babicka, Jasińska-Socha 2012, s. 781.

${ }^{19}$ Relacje likwidatorów zawiera książka Pawła Sekuły Likwidatorzy Czarnobyla. Nieznane historie - narracje świadków, buntujących się mieszkańców krajów nadbałtyckich (Sekuła 2018).

${ }^{20}$ Ułasiewicz, Dauhulewicz 2009, s. 406.

${ }^{21}$ Aleksijewicz 2012, s. 258-259.

${ }^{22}$ Aleksijewicz 2012, s. 204.
} 
Inny autor z przekonaniem pisze: „Życie toczyłoby się zwyczajnie, nawet upadek Związku Radzieckiego nie byłby w stanie spowodować przesiedlenia ludności na taką skalę, które spowodował Czarnobyl [Жыццё б ішло сваім звычайным парадкам, i нават развал Савецкага Саюза не здолеў бы справакаваць такога маштабнага перасялення люду адсюль, якое змог справакаваць Чарнобыль] [ttum. - JKD]”23. Patriarchalna wieś poleska $z$ jej tradycyjnym układem i obrzędowością, archaicznymi zwyczajami, bardzo żyzną, dającą obfite plony ziemią oraz jej mieszkańcy, którzy nie byli chętni do przeprowadzki do większych miast. Nawet ci, którzy wyjechali w latach 70 . XX w. do Homla czy Mińska za pracą, niemal co tydzień przyjeżdżali do rodziców, wysyłali swoje dzieci do dziadków na wakacje, niektóre kobiety w ciąży jechały z miasta, żeby niemowlę przyszło na świat tam, gdzie także im odcięto pępowinę - „ich więź z ojcowizną była nierozerwalna [(...) сувязь з роднымі мясцінамі заставалася для ix непарыўнай] [tłum. - JKD]"24.

Nasza wieś i okolice znane są z czarnoziemia i lasów. Urodzajne gleby, można było na nich siać przez kilka lat bez przerwy, na przykład kartofle. Ziemia dawała plony. Poza tym jest łatwa do uprawy, w niej w ogóle nie było kamieni [Наша вёска і ваколіцы - гэта край чарназёмаў і лясоў. Урадлівая глеба, на якой можна было шмат гадоў запар сеяць, напрыклад бульбу. I глеба не выраджалася. Да таго ж яе зручна апрацоўваць, бо ў ёй не было камянёў $]^{25}$. [tłum. - JKD]

Pisarka prozy dokumentalnej ujęła spostrzeżenia na temat miejscowych mieszkańców i ich domostw innego uczestnika dziejów, fotografa, który wydarzenia towarzyszące wysiedleniu udokumentował na zdjęciach:

Twarze starych chłopów, podobne do ikon... Oni najmniej rozumieli z tego, co się wydarzyło. Nigdy nie porzucali swojej zagrody, swojej ziemi. Przychodzili na świat, kochali, w pocie czoła zdobywali chleb powszedni, przedłużali ród... Z nadzieją, że doczekają wnuków... A kiedy przeżyli życie, w pokorze porzucali tę ziemię, odchodząc do niej, stając się nią. Chata białoruska! To tylko dla nas mieszczuchów, dom jest maszyną do życia. Dla nich - całym światem. Kosmosem. Wiktor Łatun, fotograf ${ }^{26}$.

Ta dygresja okaże się bardzo ważna w zrozumieniu tego, czego szukali ci ludzie po wysiedleniu na tzw. „czyste” tereny. Mieszkańcy Polesia są powiązani mnóstwem nici z własną ziemią, wielkimi wioskami, tonącymi w zieleni sadów:

${ }^{23}$ Bałachonau 2014, s. 153.

${ }^{24}$ Por.: Bałachonau 2014, s. 153.

${ }^{25}$ Machnacz 2016.

${ }^{26}$ Aleksijewicz 2012, s. 228. 
Oni się zespolili z własną wsią, z tym miejscem, w którym przyszli na świat, zapuścili korzenie. Nie da się ich stąd wyciągnąć. [Зрасліся яны 3 вёскаю, з тым кутком, дзе нарадзіліся, карані пусцілі. Не вырваць.] [tłum. - JKD] ${ }^{27}$

Sami tak komentują określenie czarnobylec:

Jak nas nie nazywano! Przesiedleńcy. Ofiary katastrofy. Likwidatorzy. Najbardziej popularny wśród mińszczan pozostaje „tytuł honorowy” - czarnobylec [Як толькі нас не называлі! Перасяленцы. Пацярпелыя ад аварыі. Ліквідатары. Найбольш ходкім ва узжытку мінчан засталося „ганаровае званне” - чарнобылец] ${ }^{28}$. [ttum. - JKD]

Po awarii elektrowni w Czarnobylu autochtoni przeżyli nie tylko stan zagrożenia promieniowaniem, ale także bolesne uczucie odrzucenia ze strony innych (nieraz nawet swoich bliskich krewnych), którzy „strefy” nie doświadczyli. Teraz byli „oni - czarnobylcy” $i$,inni”, a raczej „obcy - nie czarnobylcy”:

Od pierwszych dni poczuliśmy, że jesteśmy czarnobylcami, teraz już odtrąconymi. Że się nas boją. Autobus, którym jechaliśmy, zatrzymał się na noc w jakiejś wsi. Ludzie na podłodze w szkole, w klubie. Nie było gdzie szpilki wetknąć. Wtedy pewna kobieta zaprosiła nas do siebie: „Chodźcie, pościelę łóżko. Żal mi waszego chłopca”. A druga, stojąca obok, odpychała ją od nas: „Zwariowałaś! Są zarażeni”. Kiedy przenieśliśmy się do Mohylewa i syn poszedł do szkoły, pierwszego dnia od razu do domu z płaczem... Bo posadzili go razem z dziewczynką, a ta nie chciała siedzieć z napromieniowanym, bo boi się umrzeć. Syn chodził do czwartej klasy, w której był jedynym uczniem z Czarnobyla. Wszyscy się go bali, nazywali „świetlikiem”... „Czarnobylskim jeżem”... Przeraziło mnie to, że tak szybko skończyło się jego dzieciństwo. Nadieżda P. Wyhowska ${ }^{29}$.

Oboje z mężem mogliśmy stąd wyjechać, ale rozmyśliliśmy się i zrezygnowaliśmy. Boimy się innych ludzi. A tutaj wszyscy jesteśmy czarnobylcy. Nie boimy się, jeśli ktoś częstuje nas jabłkami albo ogórkami z własnego ogrodu czy działki, bierzemy i jemy, nie chowamy wstydliwie do kieszeni czy do torebki, żeby potem wyrzucić. Mamy wspólną pamięć... Jednakowy los... A w każdym innym miejscu bylibyśmy obcy. Zerkają na nas krzywo, z obawą... Wszyscy przywykli do słów: „Czarnobyl”, „z Czarnobyla”, „czarnobylskie dzieci”... To przykleiło się do całego naszego życia. Ale wy nic o nas nie wiecie. Boicie się nas... Uciekacie. (...) Dowiedziałam się tego i przeżyłam w pierwszych dniach... Wzięłam córkę i pognałam do Mińska, do siostry... Moja rodzona siostra nie wpuściła nas do domu, bo miała małe

${ }^{27}$ Saczanka 1987/1989, s. 109. Por. też: Ilinicz 2006.

${ }^{28}$ Cytat za: Ułasiewicz, Dauhulewicz 2009, s. 406. Cytat pochodzi z czasopisma „Litaratura i Mastactwo”, 1998, Nr 3, s. 13.

${ }^{29}$ Aleksijewicz 2012, s. 186. 
dziecko, karmiła je piersią. W koszmarnym śnie bym sobie tego nie wyobraziła! Nie wymyśliłabym czegoś takiego. No więc przyszło nocować na dworcu. Nadieżda A. Burakowa ${ }^{30}$. $\mathrm{Na}$ początku krzywdzili nas, przywołuje wspomnienia następna rozmówczyni, wszystko minęło. „Nazywali nas «świecącymi się»” [Напачатку нас крыўдзілі, згадвае наступная суразмоўніца, але мы перажылі тое. „Называлі нас «свяцяшчыміся»”] ${ }^{31}$. [tłum. - JKD] Nieprzyjazny stosunek odczuwaliśmy nie tylko my osobiście, ale ogólnie przesiedleńcy, opowiada Kaciaryna. - Na przykład, stoisz w kolejce po chleb. On się kończy - i wtedy winą obarczają «czarnobylców», mówią, że to przez nich brakuje produktów. Tak i mówili, prosto w oczy. Wtedy czasy były trudne. Wszystkiego brakowało [„Непрыязнае стаўленьне было ня толькі да нас канкрэтна, але да ўсіх, хто перасяліўся, - апавядае Кацярына. Напрыклад, прыходзіш у краму, стаіш у агульнай чарзе па хлеб. Ён сканчаецца - i тады вінавацяць у гэтым «чарнобыльцаў», маўляў, празь іх не хапае харчоў. Так у вочы і казалі. Тады ж час быў дужа цяжкі. Усяго не хапала"] ${ }^{32}$. [tum. - JKD]

Każda zmiana w życiu człowieka budzi pewien niepokój. Rytuał, ceremonia, obrzęd, towarzyszący zmianie kompensuje ją, niweluje niewygodną sytuację zakłócającą zwykły porządek.

Podążając za grupowaniem „sekwencji obrzędowych, które towarzyszą przechodzeniu z jednego stanu do drugiego, z jednego świata (...) do drugiego" ${ }^{33}$ zaproponowanym przez francuskiego etnografa Arnolda van Gennepa na początku XX w. będę zamiennie nazywać je za autorem rytuatami przejścia i podejmę próbę wyróżnienia kolejnych ich faz: rytuatów wytaczenia (separacji), rytuatów okresu przejściowego (marginalnego) i rytuatów wtaczenia (integracji). ${ }^{34}$

\section{Separacja, rytuały preliminalne}

Rytuały wyłączenia zostały zredukowane. W sytuacji nagłego wyjazdu nie było czasu na nie, poza tym mało kto myślał, że pozostawia swój dom i dobytek na zawsze. Społeczności, które wyjeżdżały ze strefy później, zapewne miały więcej czasu na refleksję, jednak w tym fragmencie skupię się na relacjach ludności zamieszkującej tereny położone najbliżej zagrożenia.

\section{Okres przejściowy, rytuały liminalne}

Rytuały liminalne wydają się bardzo ważne z uwagi na nagłe „wyrwanie” miejscowej ludności z jej tradycyjnego świata. Przejście zaczęło się w momencie wyjścia ze

\footnotetext{
${ }^{30}$ Aleksijewicz 2012, s. 223.

${ }^{31}$ AB 19.04.2016, 14.06.2018; por.: Filipienka 26.04.2016, 02.12.2018.

${ }^{32}$ AB 19.04.2016, 14.06.2018.

${ }^{33}$ Van Gennep 1908/2006, s. 36.

${ }^{34}$ Inaczej preliminalne jako rytuały wyłączenia z dawnego świata, liminalne jako odprawiane podczas stanu przejściowego, postliminalne jako rytuały włączenia do świata nowego (Van Gennep 1908/2006, s. 45).
} 
swojego domu/podwórka, ale nie miało zakończenia, znajdowało się często w stanie permanentnym.

\section{a. Pozostawione domy, dobytek, mogiły przodków}

Każda rodzina w miejscu zamieszkania miała swój wolnostojący dom. Nie bez znaczenia jest i to, że to były domy zbudowane przez gospodarzy osobiście lub przez ich rodziców, oblane własnym potem:

Rozmówca w momencie przesiedlenia miał siedem lat. Pamięta, jak rodzice nie chcieli wyjeżdżać. „Mieli porządną gospodarkę. Mieliśmy swój dom, a tu mamy mieszkanie służbowe, państwo jest właścicielem. Wcześniej nikt o prywatyzacji nie myślał, a teraz drogo to kosztuje”. [Суразмоўцу, як высялялі (...), было сем гадоў. Згадвае, што бацькі не хацелі пераяжджаць. „У іх гаспадарка была добрая. (...) Хата ў нас была свая, а тут катэдж лічыцца дзяржаўным. Пра прыватызацыю раней ня думалі, а цяпер гэта рабіць дорага" ${ }^{35}$.] [tłum. - JKD]

Tak bardzo wszystkiego żałuję. Nie trzeba było się budować. Dostalibyśmy domek. Toż są spółdzielcze. Niech sobie i komunalne [mieszkanie] i płać sobie czynsz. Gospodarz jednak postawił na swoim. Zaczęliśmy stawiać dom. Tyle wysiłku włożono. W zeszłym roku namyśliliśmy się jeszcze kocioł wymienić. Sam go pilnuje. Wyczyści, napali, i wykładzinę położy, żeby czysto było. Później po remoncie ogrzewania, wytapetowaliśmy [mieszkanie]. Tapety nowe Maryna nasza w Słucku kupiła. A teraz szykuj się w podróż. [Я так жалею ўсяго етага. Нада было ні строіцца. Далі б домік. Це ж капіраціўные. Ніхай сабе гасударствінны і плаціць за яго. Но хазяін настоіў на сваём. Пачалі ставіць дом. Аддалі стока сілы. У прошлам гаду шчэ вздумалі кацёл міняць. Ён сам іво смотрыт. Вычысця, натопя і пасцеля палавік, што б было чыста. Пожжы послі паравога, піраклеілі. Абоя новага наша Марына купіла в Слуцке. I вот збірайся ў дарогузб [tłum. - JKD]

Dom miałam porządny, pokoi, pokoi, że hej! Siedem chlewików: dla kur, dla krów, dla świń, wszystko zostawiłam. Wszystko zostawialiśmy, jak nas wysiedlali! [Хата ў мяне была дабрэнная, ох, комнат, комнат! Сем хлеўчыкоў: і на куры, і на кровы, і на свіння, усё пакідала. (...) Усё ж пакідалі, як нас вуселілі!37] [tłum. - JKD]

Tam zostawiłam (jako sierota budowałam) nowy dom. Gospodarz dach blachą nakrył. Zbudowaliśmy duży chlew. Trzymaliśmy krowę, świnie, gęsi... Wszystko zostawiliśmy. (...) „Co ja zostawiłam? Dom, chlew, dwa lata będzie, jak został wybudowany. Studnię wykopaliśmy i sad posadziliśmy. Dom chcieliśmy oszalować, szalówki nawieźliśmy. Były koty, psy, kaczki i kury - wszystko tam pozostało". [Там жа кінула (сіратою будавала) новую хату.

\footnotetext{
${ }^{35}$ AB 19.04.2016, 14.06.2018.

${ }^{36}$ Kurcowa 1994, s. 150.

${ }^{37}$ Klimczuk, Łobacz, Truchan 1994, s. 23.
} 
Гаспадар яе бляхай накрыў. Сарай вялікі пабудавалі. Карову трымалі, свінні, гусі былі... I ўсё кінулі. (...) „Што я пакінула? Дом, сарай, які толькі два гады як пабудавалі. I калодзеж выкапалі, і сад пасадзілі. I дом шаляваць хацелі, дык шалёўкі накідалі. Былі і каты, і сабакі, і качкі, і куры - і ўсё засталося там"38.] [tłum. - JKD]

Przesiedlenie scenerią przypominało czasy wojny z jedną tylko różnicą, że ludzie uciekali przed niewidocznym wrogiem, ponieważ zagrożenia radionuklidami nie da się naocznie zobaczyć:

To zachowanie wydawało mi się czymś znajomym, chociaż urodziłam się po wojnie. Starałam się analizować swoje uczucia i byłam zdumiona, jak szybko psychika się przestawia, jak niepostrzeżenie zdobyłam doświadczenie wojny. Umiałam sobie wyobrazić, jak porzucę dom, jak wyjedziemy z dziećmi, jakie rzeczy zabierzemy, co napiszę mamie ${ }^{39}$.

Żołnierze wchodzili do wsi i ewakuowali ludzi. (...) Ludzie porzucali swoje domy w obecności żołnierzy, to było przygnębiające, zwłaszcza dla tych, którzy przeżyli wojnę. (...)

(...) Mama nie mogła znieść wysiedlenia. Po roku umarła. A mnie się ciągle śnią dwa sny... Pierwszy - widzę nasz pusty dom, a drugi - przy naszej furtce wśród georginii stoi mama... Żywa... I uśmiecha się...

Cały czas porównujemy to z wojną. Ale wojnę można zrozumiećt ${ }^{40}$.

Wtedy byli wojskowi, dużo było wojskowych we wsi, bili okna, strasznie! [Тады былі ваенныя, багата было ваенных у дзярэўні, білі вокны, страх! $\left.!^{41}\right]$ [ttum. - JKD]

W sytuacji, kiedy przeprowadzka jest wcześniej zaplanowana, istnieje możliwość spakowania swoich rzeczy przed wyjazdem. Człowiek zabiera wszystkie przedmioty będące w dobrym stanie, które będą jeszcze służyły mu na nowym miejscu. Teksty pokazują, że zaistniała sytuacja miała charakter ekstremalny. Na miejscu pozostawiono narzędzia, ubrania (nawet pranie na dworze), zwierzęta domowe, porzucano pamiątki rodzinne. Na porządku dziennym były obrazy jak z kina science fiction:

(...) wózek dziecięcy na podwórzu domu z zabitymi oknami, na wózku jak na gnieździe siedzi wrona... (...). Chciałoby się utrwalić w pamięci wszystko: globus na dziedzińcu szkolnym, rozjechany przez traktor, poczerniałą wypraną bieliznę, która wisi już kilka lat na balkonie, lalki, które się postarzały na deszczu... (...) Ludzie uciekli, żyją teraz tylko na wiszących na ścianach zdjęciach. Wiktor Łatun, fotograf ${ }^{42}$.

\footnotetext{
${ }^{38}$ Siwiec, Biańko 16.04.2016, 27.11.2018.

${ }^{39}$ Aleksijewicz 2012, s. 176.

${ }^{40}$ Aleksijewicz 2012, s. 176-177.

${ }^{41}$ Klimczuk, Łobacz, Truchan 1994, s. 25.

${ }^{42}$ Aleksijewicz 2012, s. 225, 227-228.
} 
Cisza... Tam jest taka cisza! Całkiem inna niż tutaj... I nagle w tej ciszy słychać dziwną ludzką mowę: „Dobry Gosza. Dobry Gosza”. Na starej jabłoni kołysze się zardzewiała klatka z otwartymi drzwiczkami. Oswojona papuga mówi sama do siebie. Lilija M. Kuzmienkowa ${ }^{43}$.

W samej strefie... Tam nawet dźwięki są inne... Wchodzi się do domu i ma się takie wrażenie, jakby się wchodziło do śpiącej królewny. Pozostawione fotografie, meble, sprzęty domowe... Jeśli ich jeszcze nie rozkradli. Gdzieś obok powinni być ludzie. I niekiedy ich znajdujemy... Natalia A. Rosłowa, przewodnicząca Mohylewskiego Komitetu Kobiet „Dzieci Czarnobyla”44.

W domu zostawiliśmy mojego chomika, zamkniętego. Zostawiliśmy mu jedzenia na dwa dni. A wyjechaliśmy na zawsze." Chór dziecięcy ${ }^{45}$.

„Porzucony dom... Zamknięty. Kotek w oknie. Myślałem, że to gliniany. Podchodzę żywy. Objadł wszystkie kwiaty w doniczkach, geranium. Jak tam się dostał? Czy może go zostawili? Na drzwiach karteczka: „Kochany przechodniu, nie szukaj cennych rzeczy. Nie mieliśmy ich. Korzystaj ze wszystkiego, ale nie szabruj. My tu wrócimy". Na innych domach widziałem napisy różnymi kolorami: Przebacz mi, domu rodzinny!" Żegnali się z domem jak z żywym człowiekiem. Pisali: „Wyjeżdżamy rano” albo „Wyjeżdżamy wieczorem”, stawiali datę, podawali nawet godzinę i minutę. Kartki z zeszytów szkolnych zapisane dziecinnym pismem: „Nie bij kota. Bo szczury wszystko zjedzą”. Albo: „Nie zabijaj naszej Żulki. Jest dobra”. Chór żołnierzy ${ }^{46}$.

\section{b. Wysiedlenie ze strefy w ocenie autochtonów}

Masowe przesiedlenie zaczęło się dopiero w 1990 roku $^{47}$. Najczęstsze opinie miejscowych ludzi, zwłaszcza starszych, są negatywne:

Ludzie płaczą, chodzą - rzuć teraz wszyściutko, przez cały wiek ciężko pracowaliśmy. Nie chcieli na początku ludzie wyjeżdżać. Milicja przyjeżdżała. (...) Wtedy podstawili dużo maszyn, ludzie zaczęli do nich wsiadać. Lamentowali na całą wieś, płakali. [Ну людзі ж плачуць, ходзяць - кідай сваё ўсё на свеце, гараваў ж век. Ой не, не хацелі ж зразу людзі вуяжджаць. Міліцыя прыяжджала. (...) I тады ўжэ падвезлі машын багата, пагружалі этых людзей. Галосяць на ўсю дзярэўню людзі, плачуць ${ }^{48}$. [tłum. - JKD] Przyszło rozporządzenie o przesiedleniu. Ci jadą, a serce boli, wychodzi, że wojny nie ma, a jednocześnie „wojna” jest. Kto wyjechał - wszyscy żałują: byłoby lepiej, jak byśmy zostali. Wszystko jedno, i tam poumierali, kto wyjechał, a do kogo śmierć przyszła, a my i tutaj

\footnotetext{
${ }^{43}$ Aleksijewicz 2012, s. 230.

${ }^{44}$ Aleksijewicz 2012, s. 257-258.

${ }^{45}$ Aleksijewicz 2012, s. 261.

${ }^{46}$ Aleksijewicz 2012, s. 81.

${ }^{47}$ Żarskaja 2010, s. 107.

${ }^{48}$ Klimczuk, Eobacz, Truchan 1994, s. 24.
} 
jeszcze żyjemy, i wszystko. Mówią, że jeśli pojedziesz z takiej strefy do innej strefy, czystej, to szybciej umrzesz. [„Ну, прыказ прыйшоў так... выселіць. А этыя едуць, ой, а за душу бярэць, што як усё роўна вайны не было, а вайна. Хто этыя паехаў - усе каюцца: лучшэ б мы тут былі. Ну ўсё роўна ж, і там памёрлі, хто выехаў, к каму смерць прыйшла, а мы шчэ во жывём, і ўсё. Гавораць, еслі паедзеш із такой зоны ўжо ў другую зону, чыстую, так скарэй памрэш."]

Dużo ludzi wyjechało, tak! Niektórzy powrócili, my na przykład... A ci umarli z tęsknoty i z wszystkiego. Mówię, żeby ten Ochar wtedy nie pojechał do tych Maciut, oni, ci starcy, i po dziś dzień jeszcze by żyli, na pewno. A tak oni umarli z tęsknoty i smutku. No dobrze, jestem młoda, mówię, pojechałam z rodziną, z mężem i synem, i też nie dawałam sobie rady, płakałam jak bóbr. [„Ой, многа людзей павыязджала, угу! Ну, назад паварочаліся некатарыя, мы вот... А хто памёрлі ад таскі ды ад усяго. Я гавару, каб эты Охар тады не паехаў у тыя Мацюты, яны і па сённяшні дзень старікі тыя б жылі, вось што. А так яны паўміралі ад таскі, ад пячалі. Ладна ж, я маладая, гавару, я паехала з сям'ёю 3 мужыком сваім і сынам, і то я тады не магла выдзержаць, плакала горкімі слязамі"] ${ }^{49}$. [tłum. - JKD]

Śmierć z rzekomej „tęsknoty i smutku”, nie z choroby czy starości jest bardzo wymowna, taki tok myślenia pokazuje jak mocna może być więź emocjonalna $z$ własnym światem i jak trudno sobie ułożyć życie w oderwaniu od niego. Życie w oddali traci swój sens, ponieważ nie można automatycznie stać się swoim na nowym miejscu, jak nie można automatycznie zaakceptować nowego locum, nowej społeczności i jej zwyczajów.

\section{c. Pożegnanie starej przestrzeni}

Tradycyjny świat tych ludzi, symbiozę świata człowieka ze światem zwierząt i roślin oraz jego przedchrześcijańskie myślenie przedstawia kolejny fragment prozy dokumentalnej:

Chciałam opowiedzieć jak babcia żegnała się z naszym domem. Poprosiła tatę, żeby przyniósł ze spiżarni worek kaszy, i rozrzuciła ją po ogrodzie: „To dla ptaszków bożych”. Zebrała na sito jajka i wysypała na podwórzu: „Dla naszego kota i psa”. Nakroiła im słoniny. Wysypała ze wszystkich swoich woreczków nasiona: marchwi, tykwy, ogórków, cebuli... Różnych kwiatów... Rozsypała wszystko po ogrodzie... Ukłoniła się przed szopą... Obeszła wszystkie jabłonie i każdej się ukłoniła... Chór dzieci ${ }^{50}$.

W świadectwach często pojawia się motyw ziemi. Glebę mieli tam bardzo żyzną, dającą dobre plony. Nie było tam kamieni, które przeszkadzają w obróbce roli.

${ }^{49}$ Żarskaja 2010, s. 107.

${ }^{50}$ Aleksijewicz 2012, s. 262-263. 


\section{d. Zabrać ze sobą do nowego miejsca}

Ten, kto przeprowadza się do nowego miejsca, zabiera ze sobą członków rodziny, zwierzęta domowe, meble, ubrania, naczynia, narzędzia i inne przedmioty codziennego użytku. Sytuacja była osobliwa, a zarazem niejednorodna. Osobliwa, ponieważ nie z każdego miejsca można było wszystko zabrać z uwagi na zagrożenie promieniowaniem. Niejednorodna, ponieważ nawet w jednej miejscowości stosowano kilka różnych podejść i rozwiązań, nie zawsze i nie wszystko znajdowało uzasadnienie. Następujące fragmenty ilustrują sposób postrzegania wartości:

- ikona, kot i tobołek

Wchodzimy z żołnierzami do chałupy. Mieszka tam samotna babcia.

„No, babciu, jedziemy”. „Pojedziemy dzieci”. „No to zbieraj się, babciu”.

Czekamy na ulicy, palimy papierosy. No i ta babcia wychodzi, w rękach trzyma ikonę, kotka i węzełek. To wszystko, co zabiera ze sobą.

„Babciu, kota nie wolno. Zabronione. Ma radioaktywną sierść”.

„Nie, dzieci drogie, bez kotka nie pojadę. Jakże go tu zostawię samego? To moja rodzina”. Siergiej Gurin, operator filmowy ${ }^{51}$.

- zdjęcia, dokumenty

Dzieciom powiedziano: „Koniecznie zabrać ze sobą podręczniki.” Mąż jednak włożył do teczki dokumenty i nasze zdjęcia ślubne. A ja... Jedno, co zabrałam, to chustkę z gazy na przypadek złej pogody... Nadieżda P. Wyhowska, wysiedlona z miasta Prypeć52.

- ziemia z mogiły rodziców

Wzięłam do woreczka ziemię z matczynego grobu. Uklękłam na chwileczkę: „Wybacz, że cię zostawiamy". Poszłam na grób mamy w nocy i nie bałam się. Ludzie pisali na chałupach swoje nazwiska. Na belkach, na płocie. Na asfalcie. Monolog pewnej wsi o tym, jak wzywa się dusze z nieba, żeby z nimi popłakać i zjeść obiad ${ }^{53}$.

Bardzo ważnym miejscem dla tych ludzi jest cmentarz z grobami przodków. Święto Radonicy jako święto zmarłych, obchodzone przez wyznawców prawosławia w drugi wtorek po Wielkanocy, przekształciło się w dzień spotkań. Wtedy bowiem można bez pozwolenia władz przyjechać do strefy czarnobylskiej.

\footnotetext{
${ }^{51}$ Aleksijewicz 2012, s. 124.

${ }^{52}$ Aleksijewicz 2012, s. 186.

${ }^{53}$ Aleksijewicz 2012, s. 55.
} 
- drzwi do mieszkania

Było tak... W radiu ogłoszono: „Nie wolno zabierać kotów!”(...) „Nie wolno zabierać rzeczy!"Wszystkich nie wezmę, wezmę tylko jedną. Tylko jedną! Muszę zabrać drzwi z mieszkania i wywieźć, nie mogę ich zostawić... A wejście zabiję deskami...

Nasze drzwi... Nasz talizman! Rodzinna relikwia. Na tych drzwiach leżał mój ojciec. Nie wiem, nie wszędzie tak jest, ale u nas, jak mi opowiadała mama, nieboszczyka powinno się położyć na drzwi jego domu. I tak ma leżeć, dopóki nie przywiozą trumny. Siedziałem przy ojcu cała noc, leżał na tych drzwiach... Dom był otwarty... Całą noc... I właśnie na tych drzwiach były nacięcia, aż do samej góry... Jak rosłem... Zaznaczone: pierwsza klasa, druga. Siódma. Przed wojskiem... A obok - jak rósł mój syn... Jak rosła moja córka... Całe nasze życie zapisane jest na tych drzwiach, jak na starożytnych papirusach.Jakże mam je zostawić? Poprosiłem sąsiada (miał samochód): „Pomóż!” Pokazał na moją głowę... „Ty chyba? Bracie, coś nie tego". Ale wywiozłem je... Te drzwi... Nocą... Na motocyklu... Wywiozłem przez las... Zabrałem po dwóch latach, kiedy nasze mieszkanie było już obrabowane. (...)

Córka skończyła sześć lat. Dokładnie w dniu awarii. Układam ją do snu, a ona szepcze mi do ucha: „Tatusiu, ja chcę żyć, jestem jeszcze mała.” (...)

Położyliśmy ją na drzwiach... Na drzwiach, na których kiedyś leżał mój ojciec. Dopóki nie przywieźli trumienki... Była malutka jak pudełko dla dużej lalki.] Nikołaj Fomicz Kaługin, ojciec $^{54}$.

Nie jest to szeroko znana tradycja, choć rola drzwi jako wejścia „broniącego dostępu do drugiego świata” jest doskonale opisana. Drzwi stanowią granicę między światem zewnętrznym a domowym ${ }^{55}$.Zdejmowanie drzwi podczas pogrzebu może świadczyć np. o umożliwieniu „wydostania się śmierci” z domu, żeby więcej nikt z domowników nie umart.

\section{Integracja, rytuały postliminalne}

\section{a. Nowe miejsce zamieszkania}

Warunki, w których znaleźli się przesiedleńcy, były różne. Nieraz nowe domy powstawały w ciągu kilku dni, były zimne, miały wadliwe wykończenie, innym razem były to komfortowe i bardzo wygodne mieszkania. Pomijając kłopoty bytowe i stosunek otoczenia, ludzie borykali się z problemem odnalezienia poczucia „bycia u siebie”:

Z Czarnobyla zaczęto ich przesiedlać do „Europy”, do osiedli typu zachodniego. Można zbudować lepszy, wygodniejszy dom, ale przecież nie da się w nowym miejscu odbudować tego całego olbrzymiego świata, z którym ci ludzie byli złączeni. Złączeni pępowiną! Dla

\footnotetext{
${ }^{54}$ Aleksijewicz 2012, s. 52-53.

55 Np.van Gennep 1908/2006, s. 44-45.
} 
psychiki człowieka to niesamowity cios. Zerwanie z tradycją, z całą odwieczną kulturą. Kiedy się przyjeżdża do tych nowych osiedli,wyglądająjak jakaś fatamorgana. Pomalowane błękitne, granatowe, żółto-czerwone. Nazwy mają Majowe, Słoneczne. Zachodnie domki jednorodzinne są o wiele wygodniejsze niż tamte chałupy. To już gotowa przyszłość. Ale w przyszłość nie wolno zrzucać ludzi na spadochronie... Ludzi zmieniono w Papuasów... (...). Nie cieszą się z uzyskanej szansy. „Wyrwano mnie z piekła, mam dom, czystą ziemię i powinienem ratować swoje dzieci? Które mają już Czarnobyl we krwi, w genach”. Nie, czekają na cud... (...)

Mieszkają w tych domkach jak w wolierach. Domy rozwalają się, rozsypują. Mieszka tam człowiek pozbawiony wolności. Skazaniec. Żyje w poczuciu krzywdy, strachu i nawet gwoździa tam nie wbije. Natalia Rosłowa, przewodnicząca Mohylewskiego Komitetu Kobiet „Dzieci Czarnobyla ${ }^{56}$.

\section{b. Sposób oswajania nowej przestrzeni}

Wiele osób garnie się do pracy na ziemi, która działa jak terapia. Anna Engelking podkreśla:

Praca na ziemi - obok wiary w Boga i rodzinno-rodowego zakorzenienia we wspólnocie wiejskiej - zawsze należała do wartości podstawowych tradycyjnych społeczności chłopskich. Nie inaczej jest w przypadku białoruskich kołchoźników - grupy kontynuującej etos i tożsamość dawnych społeczności rolniczych z obszaru Białorusi: chłopów pańszczyźnianych, później gospodarzy i parobków, a także schłopiałej drobnej szlachty ${ }^{57}$.

Miejscowa ludność jest bardzo ściśle związana z ziemią i pracą na roli, w sadzie, w ogrodzie.

Nasza nie tylko mowa, gwara jest inna, tradycje też są nieco inne. Na przykład, w naszych wioskach tradycyjnie koło domu sadzi się drzewa, a tu tego nie ma. $\mathrm{Z}$ mężem staramy się coś tu od nas wprowadzić, z naszej ojcowizny. Lubimy sadzić drzewa, a ja uwielbiam kwiaty. Jak przychodzi wiosna, ja razem z przyrodą jakbym się budziła, zaczyna się praca na dworze, trochę pomaga na smutek [У нас не толькі мова, дыялект адрозніваюцца, але і традыцыі крыху іншыя. Напрыклад, на нашай радзіме заведзена ля кожнага дома садзіць дрэвы, а тут такога няма. Мы з мужам заўсёды стараліся і стараемся ўкараніць на новым месцы нешта адтуль, з нашай радзімы. Любім садзіць дрэвы, а я дык увогуле захапляюся кветкамі. Калі прыходзіць вясна, я, як і ўсё, нібы крыху ажываю, бо пачынаецца праца на вуліцы, а гэта не так дае мне сумаваць ${ }^{58}$. [ttum. - JKD]

\footnotetext{
${ }^{56}$ Aleksijewicz 2012, s. 258-259.

${ }^{57}$ Engelking 2012, s. 138.

${ }^{58}$ Kawalenka 30.04.2012, 30.11.2018.
} 
Zaczynając od wczesnej wiosny i do późnej jesieni Hanna Paułauna z mężem spędzają większość czasu na działce. Pawieł Mikałajewicz zbudował tam niewielki, ale przytulny i ładny domek. Najlepszym odpoczynkiem dla nich jest praca we własnym ogródku [3 ранняй вясны да позняй восені Ганна Паўлаўна 3 мужам прападае на лецішчы. Павел Мікалаевіч пабудаваў на ўчастку невялічкі, але ўтульны і прыгожы дамок. Душой адпачываюць яны, калі корпаюцца на градках] $]^{59}$. [tłum. - JKD]

Większość ludzi ma problem z zadomowieniem się na nowym miejscu. Charakteryzuje ją brak woli i niemoc, by ponownie uformować swoją przestrzeń. Jak pisała Hanna Buczyńska-Garewicz, dom, miejsce, okolica, bliska i przyswojona, mają swe źródła w doznaniach, przeżyciach, nastrojach, działaniach - słowem w doświadczeniu $\dot{z}_{y c i a}{ }^{60}$. Przesiedleńcy znajdują się w stanie przypominającym acedię ${ }^{61}$. Są zniechęceni, obojętni i przygnębieni, przestali troszczyć się o własny byt. Nie znajdują żadnej motywacji do działania w swoim nowym locum. „Wzrok uległego acedii tkwi ciągle w oknie”mówił Ewagriusz z Pontu - wskazując niechęć do miejsca jako jej główny symptom ${ }^{62}$.

Dali nam nowy dom. Murowany. No i, wie pani, przez siedem lat nie wbili my ani jednego gwoździa. Jak na obczyźnie żyjemy! Wszystko tu obce. Mój chłop płakał. Przez tydzień w kołchozie jeździ na traktorze, czeka na niedzielę, a w niedzielę kładzie się twarzą do ściany i płacze. Monolog pewnej wsi o tym, jak wzywa się dusze z nieba, żeby z nimi popłakać i zjeść obiad ${ }^{63}$.

Jak wynika z rozważań H. Buczyńskiej-Garewicz, można wnioskować, że ci ludzie „nie posiadają ugruntowanej własnej tożsamości”, są oni raczej zakorzenieni i wrośnięci w ziemię ${ }^{64}$.

Człowiek zakorzeniony jest skazany na miejsce, z którego pochodzi, i pozbawiony czegoś, co daje mu zadomowienie (zamieszkiwanie) - wolności wobec przestrzeni i możliwości stałego rozszerzania przestrzeni duchowo przyswojonych. Słowem, nie tracąc miejsca, z którym czuje się związany, może je znacznie rozszerzać $(\ldots)^{65}$.

Przesiedleni, mieszkający nieraz u swoich dzieci w dużych miastach w wysokich wieżowcach, patrzą przez okna z nadzieją, że zobaczą tam sąsiadkę sprzed lat.

\footnotetext{
${ }^{59}$ Saniuk 26.04.2018, 28.11.2018. Por. także: Kuchta 25.04.2018, 24.11.2018.

${ }^{60}$ Buczyńska-Garewicz 2006, s. 13.

${ }^{61}$ Zatorski 2008.

${ }^{62}$ Cytat za: Sieroń-Galusek, Galusek 2012, s. 100.

${ }^{63}$ Aleksijewicz 2012, s. 57.

${ }^{64}$ Buczyńska-Garewicz 2006, s. 110-111.

${ }^{65}$ Buczyńska-Garewicz 2006, s. 111.
} 
„Codziennie... Codziennie chodzę po swoich wspomnieniach... Tymi samymi ulicami, koło tych samych domów (...)" Ludowy chór ${ }^{66}$.

- Raz mi się śniło, już kiedy u syna w mieście mieszkałam, że czekam na śmierć. I synom nakazuję: „Zawieźcie mnie na nasze groby, chociaż pięć minut postójcie ze mną przy rodzinnym domu". I z góry widzę, jak synowie mnie tutaj wiozą...

- Może sobie być zatruta, napromieniowana, ale to moja ojczyzna. Nigdzie indziej nie jesteśmy potrzebni. Nawet ptakowi własne gniazdo jest miłe.

- Niech dokończę... Mieszkałam u syna na szóstym piętrze, nieraz podejdę do okna, popatrzę w dół i się przeżegnam. Bo zdawało mi się, że słyszę konia. Koguta... I taka żałość... Albo śniło mi się nasze podwórze: przywiązuję krowę i doję, doję... Potem się budzę. I nie chce mi się wstawać. Jestem jeszcze tam. Jestem to tu, to tam.

- Za dnia żyliśmy w nowym miejscu, a nocą u siebie. We śnie. Monolog pewnej wsi o tym, jak wzywa się dusze z nieba, żeby z nimi popłakać i zjeść obiad ${ }^{67}$.

Babcia... Nie przyzwyczaiła się do nowego miejsca. Tęskniła. (...) Katia P.68.

Pomocne są podobne doświadczenia:

Mnie uratowała moja mama. W ciągu swojego długiego życia nie raz traciła dom, pierwszy raz w latach trzydziestych, kiedy była represjonowana, zabrali im wszystko - krowę, konia, chałupę. Drugi raz - pożar, tylko mnie, małą, wyrwała z ognia: „Trzeba to przetrwać - pocieszała mnie. - Przecież żyjemy”. Nadieżda P. Wyhowska ${ }^{69}$.

W domu 82-letnia starsza pani. Czarnobylskie wygnanie drugie w jej życiu. Niescierowna była wywieziona do faszystowskich Niemiec, wiele przeżyła [Дома - 82-гадовая бабуля (...). Чарнобыльскае выгнанне - другое ў яе лёсе. Несцераўна (...) была вывезена ў Германію, багата перажыла] ${ }^{70}$. [tłum. - JKD]

\section{Wnioski}

Przywiązani do ziemi, zakorzenieni w swoim miejscu ludzie nie są w stanie zadomowić się w nowym locum. Długo przeżywają nową sytuację, aż wreszcie wracają lub jedynie wegetują w nowym miejscu. Ból wynikający z rozłąki z ojcowizną, grobami najbliższych potęgują warunki bytowe, odmienne warunki naturalne (kamienie, nieurodzajna lub mniej urodzajna ziemia, brak takiej ilości jagód i grzybów) oraz odtrącenie ze strony otoczenia, co nieraz się zdarza. Jakby nie awaria elektrowni w Czarnobylu, nie

\footnotetext{
${ }^{66}$ Aleksijewicz 2012, s. 177.

${ }^{67}$ Aleksijewicz 2012, s. 55.

${ }^{68}$ Aleksijewicz 2012, s. 117.

${ }^{69}$ Aleksijewicz 2012, s. 187.

70 Kruczenka 24.01.2008, 01.12.2018.
} 
doszłoby na pewno do przymusowej migracji na taką skalę, a w jej efekcie rozległej mitologizacji domu rodzinnego.

Jak obliczyć stratę - stratę rodzinnych stron? Stratę znajomych, przyjaciół, tych pieśni, powiedzonek, legend, nazw, grobów przodków... W jakich jednostkach można te straty obliczyć? Nie ma takiej możliwości. To są rzeczy niepowtarzalne, bezcenne. Za żadne skarby ich nie kupisz ${ }^{71}$. [Як вылічыць гэту страту - страту роднай вёскі? Страта знаёмых, сяброў, тых песень, показак, легенд, назваў, родных магілаў... У якіх адзінках можна вылічыць гэтую страту? Немагчыма. Бо гэтыя рэчы непаўторныя, а значыць, i цаны ім няма. Не купіш іх ні за якія грошы.] [tłum. - JKD].

Pozostawienie swojego miejsca wpływa także na zmiany w sferze mentalności. Ludzie, zwłaszcza starsi, w nowym miejscu nie czują się dobrze, marzą o powrocie do swoich społeczności, kultury, grobów przodków, warunków przyrodniczych. Wśród strategii oswojenia i zadomowienia się w nowej przestrzeni zaobserwowano wykonywanie podobnego zajęcia, tj. pracę na działce przy domu lub domku letniskowym, skupienie się na zdrowiu własnych dzieci (czasem traktowanie domu dzieci jako swojego) oraz porównywanie własnej sytuacji do sytuacji innych ludzi, którzy doświadczyli podobnego cierpienia $\mathrm{w}$ równie ekstremalnych okolicznościach, takich jak represje, wojna, pożar. Przyjęte przez przesiedleńców sposoby radzenia sobie w nowych warunkach przynajmniej w małym stopniu są w stanie złagodzić ból pożegnania stron rodzinnych.

\section{Bibliografia}

Bartmiński J. 2018, Język w kontekście kultury czyli co dzis znaczy metafora "europejski dom"? Z prac na XVI Kongres Slawistów Belgrad, sierpień 2018 roku. „Śląsk”, Katowice.

Bartmiński J., Bielińska-Gardziel I. 2012, Polski jezykowo-kulturowy obraz domu (cz. I), [w:] Abramowicz M., Bartmiński J., Bielińska-Gardziel I. (red.), Wartości w jezykowo-kulturowym obrazie świata Stowian i ich sasiadów, 1, Wydawnictwo Uniwersytetu Marii Curie-Skłodowskiej, Lublin: s. 9-46.

Buczyńska-Garewicz H. 2006, Miejsca, strony, okolice. Przyczynek do fenomenologii przestrzeni, Universitas, Kraków.

Budzik J. 2013, Zadomowieni i wyobcowani. O sytuacji pisarzy polskich w Kanadzie, Wydawnictwo Uniwersytetu Jagiellońskiego, Kraków - Polski Fundusz Wydawniczy w Kanadzie, Toronto.

Chylak-Schroeder T., Głuszkowska-Babicka J., Jasińska-Socha T. 2012, Stownik biatorusko-pol$s k i$, Katedra Białorutenistyki Uniwersytetu Warszawskiego, Warszawa.

Dmitrenko A. 2017, «Nasze serce po rodnom kraju i teper wono botyt”: mata bat'kiwszczyna u pamjati peresetenciw iz Czornobylszczyny (za materiatamy istoryko-etnobraficznoji ekspedyciji

${ }^{71}$ Ilinicz 2006. 
2012 roku na Kyjiwszczynu, [w:] Smalenczuk A. (red.) Czarnobylskaja awaryja i hramadstwa: 30 hod pasla katastrofy, Wydawiec Zmicier Kołas, Minsk, s. 203-213 [Дмітренко A. 2017, «Наше серие по родном краю і тепер воно болить»: мала батьківщина у пам'яті переселенців із Чорнобильщини (за матеріалами історико-етнографічної експедищї 2012 року на Київину), [у:] Смаленчук А. (рэд.) Чарнобыльская аварыя $i$ грамадства: 30 год пасля катастрофы, Выдавец Зміцер Колас, Мінск, с. 203-213].

Dutka E. 2008, Okolice nie tylko geograficzne. O twórczości Andrzeja Kuśnierwicza, Wydawnictwo Uniwersytetu Śląskiego, Katowice.

Dziuban Z.2007, Hermeneutyczny wymiar doświadczenia przestrzeni,„Teksty Drugie”, 4, s. 123-129. Engelking A. 2012, „Zapracowany naród”. Praca jako rdzeń tożsamości białoruskich kołchoźników, [w:] Abramowicz M., Bartmiński J., Bielińska-Gardziel I. (red.), Wartości w językowo-kulturowym obrazie świata Stowian i ich sasiadów, 1, Wydawnictwo Uniwersytetu Marii Curie-Skłodowskiej, Lublin, s. 137-157.

Heidegger M. 1977, Budować mieszkać myśleć. Eseje wybrane, tłum. Michalski K., Czytelnik, Warszawa.

Iwanowa W. 2017, Czarnobylskaja katastrofa u dakumentach Betaruskaba archiwa wusnaj historyi, [w:] Smalenczuk A. (red.), Czarnobylskaja awaryja i hramadstwa: 30 hod pasla katastrofy, Wydawiec Zmicier Kołas, Minsk, s. 188-202 [Іванова В. 2017, Чарнобыльская катастрофа у дакументах Беларускага архіва вуснай гісторыі, [у:] Смаленчук А. (рэд.) Чарнобыльская аварыя і грамадства: 30 год пасля катастрофы, Выдавец Зміцер Колас, Мінск, с. 188-202.

Kazlouskaja-Doda Ja. 2015, Paniaccie DOM и suczasnaj bietaruskaj mowie [Казлоўская-Дода Я. Паняцие ДОМ у сучаснай беларускай мове], Wydawnictwo Uniwersytetu Marii Curie-Skłodowskiej, Lublin.

Klimczuk F., Łobacz S., Truchan T. 1994, Z haworak bytych życharou Chojnickaha, Naraulanskaha, Brabinskaha rajonau, [w:] Krywicki A. (red.), Haworać czarnobylcy (z miascowych haworak czarnobylskaj zony u Biełarusi), Instytut mowaznaustwa imia Jakuba Kołasa AN Biełarusi, Minsk, s. 8-33 [Клімчук Ф., Лобач С., Трухан Т. 3 гаворак былых жыхароў Хойніикага, Нараўлянскага, Брагінскага раёнаў, [у:] Крывіцкі А. (рэд.), Гаворащь Чарнобыльцы (з мясиовых гаворак чарнобыльскай зоны у Беларусі), Інстытут мовазнаўства імя Якуба Коласа АН Беларусі, Мінск, с. 8-33].

Kozłowska-Doda J. 2015, Dom w języku biatoruskim, [w:] Bartmiński J. (red.) Leksykon Stowian i ich sasiadów, t. 1: DOM, Bartmiński J., Bielińska-Gardziel I., Żywicka B. (red.), Wydawnictwo Uniwersytetu Marii Curie-Skłodowskiej, Lublin, s. 177-206.

Kurcowa W. 1994, Stan i razwiccio mounaj situacyi na paudniowa-uschodniaj Homielszczynie za czarnobylski czas (fanietycznyja asabliwasci miascowaj haworki i dyjalektnaha miascowaba wymaulennia), [w:] Krywicki A. (red.), Haworać czarnobylcy (z miascowych haworak czarnobylskaj zony u Biełarusi), Instytut mowaznaustwa imia Jakuba Kołasa AN Biełarusi, Minsk, s. 116-157 [Курцова В. Стан і развіциё моўнай сітуаџылі на паўднёва-уссходняй Гомельшчыне за чарнобыльскі час (фанетычныя асаблівасиі мясиовай гаворкі 
і дыялектнага мясцовага вымаўлення), [у:] Крывіцкі А. (рэд.), Гавораць Чарнобыльизы (з мясцовых гаворак чарнобыльскай зоны у Беларусі), Інстытут мовазнаўства імя Якуба Коласа АН Беларусі, Мінск, с. 116-157].

Legeżyńska A. 1996, Dom i poetycka bezdomnośc w liryce wspótczesnej, Wydawnictwo Naukowe PWN.

Eeszczenko N. 2017, Czornobylśka katastrofa u pamjati wymuszenych peresetenciw czerez 30 rokiw pisla awariji, [w:] Smalenczuk A. (red.) Czarnobylskaja awaryja i hramadstwa: 30 hod pasla katastrofy, Wydawiec Zmicier Kołas,Minsk, s. 214-225 [Лещенко Н. 2017, Чорнобильська катастрофа у пам'яті вимушених переселениів через 30 років після аварії, [у:] Смаленчук А. (рэд.) Чарнобыльская аварыя і грамадства: 30 год пасля катастрофы, Выдавец Зміцер Колас, Мінск, с. 214-225].

Paskiewicz S. 2016, Strefa Radioaktywnego Zapomnienia, tłum. M. Buchalik, „Znak”, kwiecień (Vol. 731), s. 18-25.

Sekuła P. 2018, Likwidatorzy Czarnobyla. Nieznane bistorie, Wydawnictwo Naukowe PWN, Warszawa.

Sieroń-Galusek D., Galusek Ł. 2012, Pogranicze. O odradzaniu się kultury, Kolegium Europy Wschodniej im. Jana Nowaka-Jeziorańskiego, Wrocław.

Smalenczuk A. (red.) 2017, Czarnobylskaja awaryja i hramadstwa: 30 hod pasla katastrofy, Wydawiec Zmicier Kołas, Minsk [Смаленчук А. (рэд.) 2017, Чарнобыльская аварыл i грамадства: 30 год пасля катастрофы, Выдавец Зміцер Колас, Мінск].

Sudnik M., Kryuko M. (red.) 1999, Ttumaczalny stounik bietaruskaj litaraturnaj mowy, BiełEn, Minsk [Суднік М., Крыўко М. (рэд.) 1999, Тлумачальны слоўнік беларускай літаратурнай мовы, БелЭн, Мінск].

Tischner J. 2006, Filozofia dramatu, Wydawnictwo Znak, Kraków.

Ułasiewicz W., Dauhulewicz N. 2009, Stounik nowych stou bietaruskaj mowy, TietraSistiems,

Minsk [Уласевіч В., Даўгулевіч Н. Слоўнік новых слоўбеларускаймовы, ТетраСистемс, Мінск].

Van Gennep A. 1908/2006, Obrzędy przejscia. Systematyczne studium ceremonii. O bramie i progu, o gościnności i adopcji, o ciąży i porodzie, o narodzinach, dziecinstwie, dojrzerwaniu i inicjacji, o święceniach kaptańskich $i$ koronacji królów, o zaręczynach $i$ zaślubinach, o pogrzebie i porach roku, i o wielu innych rzeczach, przeł. Biały B., Państwowy Instytut Wydawniczy, Warszawa.

Weil S. 1943/2004, Zakorzenienie. Wstęp do deklaracji obowiązków wobec istoty ludzkiej, [w:] Weil S. 2004, Dzieła, tłum. Frankiewicz M., Wydawnictwo BRAMA - Książnica Włóczęgów i Uczonych, Poznań, s. 929-1104.

Zatorski W. o. OSB (opr.) 2008, Acedia - duchowa depresja. Wybór tekstów, Tyniec, Kraków.

Żarskaja N. 2010, Czarnobylskaja awaryja u pamiaci życharou w. Wochar (Czerykauski rajon, Mabilouskaja wobtasć), „Histaryczny almanach”, t. 16, s. 102-118 [Жарская Н., Чарнобыльская аварыя ў памяці жыхароўв. Вохар (Чэрыкаўскі раён, Магілёуская вобласиь), „Гістарычны альманах”, т. 16, с. 102-118]. 


\section{Źródła prasowe, utwory literackie, wypowiedzi świadków}

AB 19.04.2016, "Zakinuli nas siudy, jak da czorta na wysietki. Pierasialency-czarnobylcy pra swajo żýcio «nа сzид̇уnie» [АБ «Закінулі нас сюды, як да чорта на выселкі. Перасялениььчарнобыльиы пра сваё жыцьиё «на чужыне»], Радыё Свабода, https://www.svaboda. org/a/pierasialiency-carnobylcy-pra-svajo-zyccio-na-cuzynie/27684322.html 14.06.2018.

Aleksijewicz S. 2012, Czarnobylska modlitwa. Kronika przyszłości, tłum. Czech J. Wydawnictwo Czarne, Wołowiec.

Bałachonau S. 2014, "Uskormleny suć pa bozie», abo kolki stou pra matuju radzimu [Балахонаў C. 2014, «Ускормлены суизь па бозе», або колькі слоў пра малую радзіму], „Аrche”, № 10, s. $153-165$.

Ilinicz N. 2006, Czarnobyl u losie adnoj siamji, Krajaznauczy sajt Talka i nawakolla [Ільініч Н., Чарнобыль у лёсе адной сям' $i$, Краязнаўчы сайт Талька і наваколля], http://old.talka. info/kpchyrnob.html, 24.09.2018.

Filipienka L. [wypowiedź w:] Januszeuskaja W. 26.04.2016, Pierasialency: bistoryja ab tym, jak Czarnobyl zmianiu losy stauharadczan, „Radzima” [Філіпенка Л. [у:] Янушэўская В. Перасялениы: гісторыя аб тыл, як Чарнобыль змяніўлёсы слауггарадчан, „Радзіма”], http://www.glusk.by/2016/04/perasyalency-gistoryya-ab-tym-yak-charnobyl-zmyaniy̆ -lyosy-slay̆garadchan/, 02.12.2018.

Kruczenka T. 24.01.2008, Ad Babczyna da Lisak szlach niablizki, portał „Prawda Homiel” [Кручэнка Т. Ад Бабчына да Лісак шлях няблізкі, портал „Правда Гомель”, https:// gp.by/category/news/society/news3778.html, 01.12.2018.

Kuchta M. 25.04.2018, „Dauno stali swaimi”, „Lachawicki wiesnik”, № 31 [Кухта M. 25.04.2018, „Даўно сталі сваімі”, „Ляхавіцкі веснік”, № 31], http://belsmi.by/archive/article/106628, 24.11.2018.

Machnacz W. 09.04.2016, Czarnobyl u twarach. Historyja adnaho pierasialennia, Homielski zialony partał [Махнач В. Чарнобыль у тварах. Гісторыя аднаго перасялення, Гомельскі зялёны партал], http://homel.greenbelarus.info/articles/09-04-2016/charnobylski -shlyah-gistoryya-adnago-perasyalennya, 18.09.2018.

Kawalenka N. [wypowiedź w:] Maksimuk A. 30.04.2012, Piaczatka Czarnobyla u losach, „Hołas czasu” [Каваленка Н. [у:] Максімук А. Пячатка Чарнобыля ў лёсах, „Голас часу”], http://www.malorita.by/?p=4553, 30.11.2018.

Saczanka B. 1987/1989, Rodny kut, [w:] Saczanka B. 1989, Rodny kut. Apowiesci, apawiadanni, narys, ese, Mastackaja litaratura, Minsk, s. 5-114 [Сачанка Б. 1987, Родны кут, [у:] Сачанка Б. 1989, Родны кут. Аповесиі, апавяданні, нарыс, эсэ, Мастацкая літаратура, Мінск, с. 5-114].

Saniuk A. 26.04.2018, Jak żywuć pierasialency z Czarnobylskaj zony u Aszmianach, „Aszmianski wiesnik” [Санюк А. Як жывуцьь перасяленцы з Чарнобыльскай зонь у Ашмянах, „Ашмянскі веснік”], http://www.osh.by/?p=42201, 28.11.2018.

Siwiec Ju., Biańko M.16.04.2016. Htuchawickija pierasialency. Czarnobyl. 30 hod pasla, Biełaruskaje Radyjo Racyja [Сівец Ю., Бянько М. Глухавіикія перасяленйьл. Чарнобыль. 30 год 
пасля, Беларускае Радыё Рацыя], https://www.racyja.com/hramadstva/glukhavitskiya -perasyalentsy/, 27.11.2018.

\section{Archiwalia}

Białoruskie Archiwum Historii Mówionej [Беларускі архіў вуснай памяці], http://nashapamiac.org/archive/archivetree.html, 30.01.2019. 